\title{
A procedure for correcting the position of plant tissue samples in accidentally polymerized glycol methacrylate resin
}

\author{
(10. Carlos André Espolador Leitão ${ }^{1,2}$
}

Received: 2 October 2017; accepted: 15 October 2018

Como citar: Leitão, C.A.E. A procedure for correcting the position of plant tissue samples in accidentally polymerized glycol methacrylate resin. Hoehnea 46: e692017. http://dx.doi.org/10.1590/2236-8906-69/2017.

\begin{abstract}
A procedure for correcting the position of plant tissue samples in accidentally polymerized glycol methacrylate resin). Glycol methacrylate resin is a very convenient medium used for inclusions of various types of tissue for histological and cytological studies. It provides excellent mechanical support in the sectioning of samples, even the ones with big differences in hardness. Additionally, it allows a large range of stain techniques and histochemical tests. During the infiltration stage, especially if it lasts for several days, the resin may be accidentally polymerized, which may give the impression that the sample has been lost. The present work aims to provide a technique for correcting the position of plant tissues samples embedded in accidentally polymerized glycol methacrylate resin. For this purpose, blocks of resin accidentally polymerized containing plant samples were trimmed and reshaped appropriately. The results were satisfactory and it was possible to obtain good sections of three micrometers thick.
\end{abstract}

Keywords: embedding, histology, historesin, plant anatomy, technique in microscopy

RESUMO - (Procedimento para correção da posição de amostras de tecido vegetal em resina de glicol-metacrilato acidentalmente polimerizada). A resina glicol-metacrilato é um meio de inclusão de grande conveniência no estudo histológico e citológico, nos mais variados tipos de tecido. Oferece excelente suporte mecânico no seccionamento de amostras, mesmo nas com grandes diferenças de dureza, e permite uma ampla gama de colorações e testes histoquímicos. Durante a etapa de infiltração, em especial quando realizada durante vários dias, pode ocorrer a polimerização acidental da resina, o que leva à impressão de que a amostra foi perdida. O presente trabalho objetivou elaborar uma técnica de correção de posição de amostras de tecidos vegetais em blocos de resina glicol-metacrilato acidentalmente polimerizada. Para este fim, os blocos de resina acidentalmente polimerizada contendo amostras vegetais foram desbastados e reincluídos adequadamente. Os resultados foram satisfatórios, obtendo-se cortes de três micrômetros de espessura com facilidade e qualidade.

Palavras-chave: anatomia vegetal, histologia, historresina, inclusão, técnica em microscopia

\section{Introduction}

Glycol methacrylate resin is a fine inclusion medium because it maintains an excellent morphological integrity of tissues (Cerri \& SassoCerri 2003). Its hardness allows its uniform sectioning, including in cases in which the structure of the organs analysed presents big differences of hardness (Quester et al. 2002). In such cases, it is customary to see, in paraffin sections, the occurrence of harder structures stretching over softer tissues. Therefore, the superiority of glycol methacrylate resin over paraffin is evident when it comes to the preservation of morphological details, including with regard to the staining of enzymes (Islam \& Henderson 1987). Besides this, it is also applicable in the inclusion and sectioning of very hard samples, such as fossils (Robison \& Miller Jr. 1975).

Although the obtainment of sections made in paraffin is faster than that of ones in resin, the infiltration and embedding procedures are much slower and more difficult, requiring the use of xylol (Johansen 1940, Berlyn \& Miksche 1976), a solvent

1. Universidade Estadual do Sudoeste da Bahia, Departamento de Ciências Naturais, Estrada do Bem Querer, Km 4, S/N, 45.031-900, Vitória da Conquista, BA, Brazil

2. Corresponding author: candreel@yahoo.com.br 
which is highly prejudicial to the sample cell (Amaral et al. 2004) and, apparently, carcinogenic (Kraus \& Arduin 1997). Very often one must submit the sample to hot vacuum in order to obtain satisfactory results (Leitão \& Cortelazzo 2008).

Glycol methacrylate resin is extremely versatile regarding staining and histochemistry, and it is possible to carry out various proceedings, both in animal and in plant tissues (Cerri \& Sasso-Cerri 2003, Amaral et al. 2004, Gomes-Filho et al. 2007, Moreira \& Isaias 2008, Oyama et al. 2010).

The manufacturer of brand Historesin ${ }^{\circledR}$ (Leica) recommends infiltrations for a short period of time. However, when carrying on a proceeding, especially in the case of plant samples, it is customary to let them infiltrating for days in resin. In such case an accidental polymerization of the resin may occur, generating bad positioning of samples into a shapeless block, in the flask in which the infiltration is being carried out.

One of the disadvantages of glycol methacrylate resin, perhaps the worst one in comparison with paraffin, is the impossibility of removing the resin, either in the sections already obtained or in the accidental polymerization during samples infiltration (Cerri \& Sasso-Cerri 2003). In the latter case, samples may be inadvertently considered lost.

The acquisition of samples is, very often, one of the most complicated steps of an experiment. An accidental fault committed during the inclusion in glycol methacrylate resin greatly prejudices the experiment. Therefore, the development of a technique to remedy an accidental polymerization of the resin can be valuable.

This experiment aims to create a procedure for recover samples in glycol methacrylate blocks accidentally made during infiltration in resin and to test the efficiency of such procedure during the obtainment of histological sections and the observation at the light microscope.

\section{Material and methods}

Samples from the apex of the inflorescence containing flower buds of Acianthera ochreata (Lindl.) Pridgeon \& M.W. Chase and Epidendrum orchidiflorum Salzm. ex Lindl. (Orchidaceae) were fixed in a solution containing $2.5 \%$ glutaraldehyde and 4\% paraformaldehyde in phosphate buffer $(\mathrm{pH} 7.2$; $0.05 \mathrm{M}$ ) with $3 \%$ sucrose (Karnovsky 1965), washed in distilled water and dehydrated in ethanol, according to the usual methodology (Berlyn \& Miksche 1976). The vouchers specimens were deposited in the Herbarium of the Universidade Estadual de Santa Cruz, Bahia, Brazil, registration numbers 21,983 and 21,975, respectively.

The whole infiltration procedure was carried out in $1.5 \mathrm{ml}$ Eppendorf ${ }^{\circledR}$ flasks. The samples were then infiltrated in glycol methacrylate resin (Historesin ${ }^{\circledR}$, Leica), initially 1:1 with $95 \%$ ethanol for 8 hours, and then submitted to infiltration resin, at $6{ }^{\circ} \mathrm{C}$. On the $13^{\text {th }}$ day, it was verified that the resin was polymerized, containing the randomly positioned samples (figure 1a). In the attempt to make historesin blocks containing these samples properly positioned, it proceeded as follows:

I- The Eppendorf ${ }^{\circledR}$ flasks were opened with a probe and the accidentally polymerized blocks were removed with tweezers (figure 1b);

II- The sharp edges were pared down with a razor blade in order to reduce, as much as possible, the amount of resin around the sample (figure 1c);

III- The small blocks already pared down were packed into polypropylene molds (Histomold ${ }^{\mathbb{R}}$, Leica) (figure 1d, e);

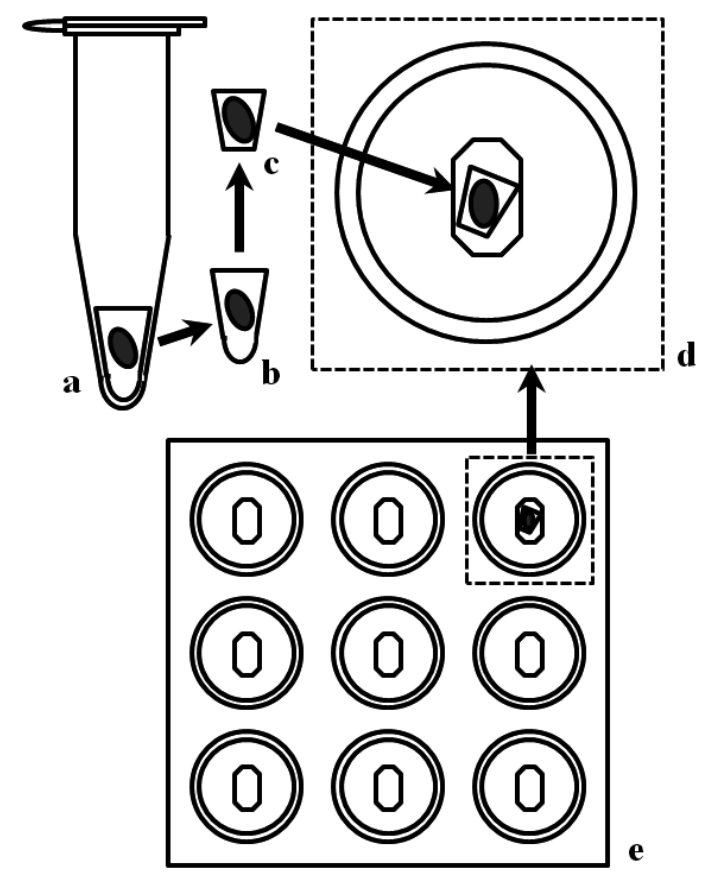

Figure 1. Scheme of the procedure for the re-embedding of blocks in historesin accidentally polymerized. (a) Eppendorf ${ }^{\circledR}$ flask containing samples in accidentally polymerized infiltration resin. (b) Block of accidentally polymerized resin removed of the Eppendorf ${ }^{\circledR}$ flask. (c) Trimmed block. (d) Trimmed block with a properly oriented sample, inside a Histomold ${ }^{\circledR}$ cell. (e) General view of a Histomold ${ }^{\mathbb{B}}$ containing a trimmed block in a cell. 

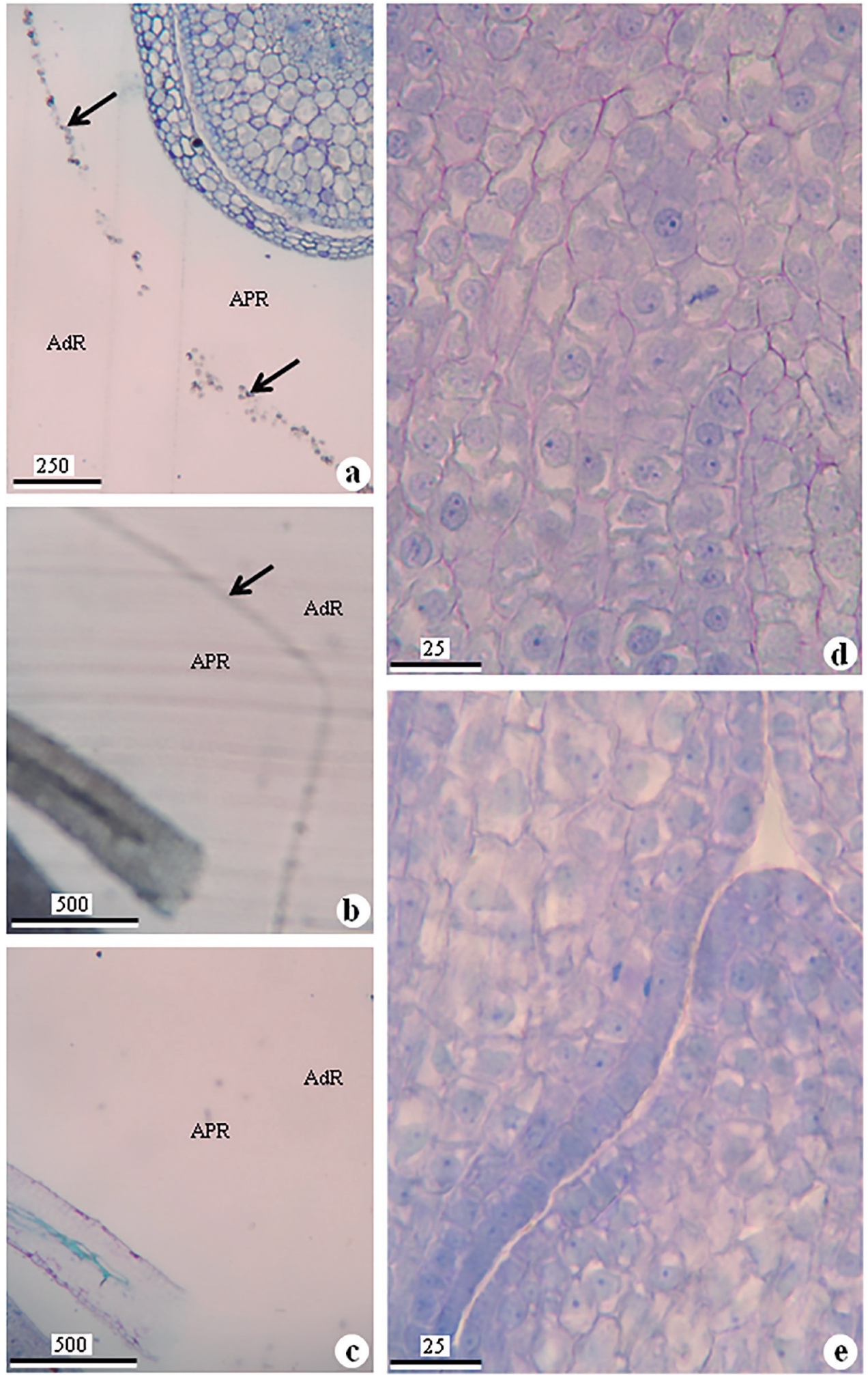

Figure 2. Micrographs of flower bud sections of Acianthera ochreata (a, d, e) and Epidendrum orchidiflorum (b, c) submitted to re-embedding (a-d) and control (e) stained with Toluidine Blue O. (a) Section on an unmounted slide evidencing the welding line consisting of small bubbles of air (arrows), between the accidental polymerized resin (APR) and the additional resin (AdR). (b) Section on an unmounted slide beyond the focal plane of the sample, evidencing the soft corrugation line between the accidental polymerized resin (APR) and the additional resin (AdR), shaped as an inconspicuous line (arrow). (c) As in (b), but with the slide mounted in water with a cover glass and focusing the sample. (d) Detail of the section of flower bud of A. ochreata re-embeded. (e) As in (d), but control. Scale bars in micrometers. 
IV- Resin with hardner was added to each cell in the mold containing a small block. During such procedure, the small blocks were positioned so that the samples were adequately oriented (figure 1d);

$\mathrm{V}$ - The molds containing the samples were placed in a drying stove for $60^{\circ} \mathrm{C}$, for 12 hours. The blocks were removed from the mold and glued to wood supports with Araldite ${ }^{\circledR}$.

The control was made with inclusions of plant samples similar to those used in the treatment, but with infiltration during one week so that the resin does not polymerize spontaneously.

In order to obtain serial sections, a Leitz 1212 rotary microtome regulated for $3 \mu \mathrm{m}$ was used. Such sections were stained with $0.05 \%$ Toluidine Blue O in pH 4.0 Mcllvaine buffer (Vidal 1977). The slides were mounted with water or not mounted, i.e., dry, with no cover glass. For analysis and photographic documenting, an Olympus CX21 microscope with digital image acquiring system was used.

\section{Results}

The blocks obtained showed a small soldering mark, visible between the resin accidentally polymerized and the additional resin. In more extreme cases, such mark consisted of small bubbles (figure 2a). In other samples, the soldering mark was inconspicuous and looked like small corrugation (figure 2b), imperceptible in the focal plan of the sample and even more difficult to see on slides mounted with water and cover glass (figure 2c). Nevertheless, in all cases, the sectioning was perfect, with no sign of rupture between the two blocks. The cytological and histological conditions of the sectioned material did not show any alteration, in comparison with the control (figure 2d, e).

\section{Discussion}

The methodology described in this paper has demonstrated its efficiency in the recovery of the samples accidentally turned into blocks by an unexpected polymerization of the infiltration resin. Apparently, the blocks of accidentally polymerized resin were completely welded to the additional resin, and the analysis at the microscope of the sections obtained showed that the polymerization of the resin was completed within the samples.

Therefore, the obtainment of young tissues sections, such as flower buds, constituted by delicate meristematic cells, indicates that the accidental polymerization of the historesin, at least in this case, did not lead to a deletion of the quality of preparations. Thus, although it is recommended to perform the inclusion according to the manufacturer's instructions, the stretching of the infiltration time leading to an accidental polymerization of the resin does not necessarily results in loss of the samples.

In the present experiment, the samples in accidentally polymerized resin were in individual flasks, which facilitated the correction of their respective positions. However, in the case of flasks containing several samples randomly positioned in an accidentally polymerized resin, it would be necessary to fractionate the block with a razor blade or scalpel in order to individualize the samples. In this case, depending on the situation, the recovery of all samples may be impossible. This is a meticulous procedure making it necessary to use a stereo microscope. It is important to remember that historesin is hygroscopic and is more flexible when relatively humid. Thus, if it is too hard, it is advisable to place the blocks in a humid chamber until they reach adequate flexibility for fractionation.

One may conclude that the procedure described here can be applied in the case of an accidental polymerization of the infiltration resin, and is especially recommended in cases when the samples are difficult to obtain or are irreplaceable.

\section{Acknowledgements}

I thank Vera Regina Pini Leitão for traduction assistance and Jacquelline Viana Fernandes, Maiara Costa Cardoso and Rosane Baleeiro Santos undergraduating in Biological Sciences, Universidade Estadual do Sudoeste da Bahia, for technical assistance.

\section{Literature cited}

Amaral D., Chiarini-Garcia H.I., Vale-Filho V.R. \& Allen, W.R. 2004. Efeito dos fixadores formalina e Bouin na preservação de biópsias do endométrio de éguas após inclusão em resina plástica. Arquivo Brasileiro de Medicina Veterinária e Zootecnia 56: 7-12.

Berlyn G.P. \& Miksche J.P. 1976. Botanical microtechnique and cytochemistry. Iowa State University Press, Iowa.

Cerri P.S. \& Sasso-Cerri E. 2003. Staining methods applied to glycol methacrylate embedded tissue sections. Micron 34: 365-372. 
Gomes-Filho J.E., Gomes B.P.F.A., Zaia A.A., Ferraz C.R. \& Souza-Filho F. 2007. Evaluation of the biocompatibility of root canal sealers using subcutaneous implants. Journal of Applied Oral Science 15: 186-194.

Islam A.E.S. \& Henderson E.S. 1987. Glycol methacrylate embedding for light microscopy I enzyme histochemistry on semithin sections of undecalcified marrow cores. Journal of Clinical Pathology 40: 1194-1200.

Johansen D.A. 1940. Plant microtechnique. McGraw-Hill Book, New York.

Karnovsky M.J. 1965. A formaldehyde-glutaraldehyde fixative of high osmolality for use in electron microscopy. Journal of Cell Biology 27: 137-138.

Kraus J.E. \& Arduin M. 1997. Manual básico de métodos em morfologia vegetal. EDUR, Rio de Janeiro.

Leitão C.A.E. \& Cortelazzo A.L. 2008. An inexpensive alternative equipment for the plant material embedding in the paraffin under vacuum. Brazilian Archives of Biology and Technology 51: 1011-1014.
Moreira A.S.F. \& Isaias R.M.S. 2008. Comparative anatomy and absorption roots of terrestrial epiphytic. Brazilian Archives of Biology and Technology 51: 83-93.

Oyama S.O., Souza L.A., Muneratto J.C. \& Albiero A.L.M. 2010. Morphological and anatomical features of the flowers and fruits during the development of Chamissoa altissima (Jacq.) Kunth (Amaranthaceae). Brazilian Archives of Biology and Technology 53: 1425-1432.

Quester R., Knifka J. \& Schröder R. 2002. Optimization of glycol methacrylate embedding of large specimens in neurological research. Study of rat skull-brain specimens after implantation of polyester meshes. Journal of Neuroscience Methods 113: 15-26.

Robison C.R. \& Miller Jr., C.N. 1975. Glycol methacrylate as an embedding medium for lignitic plant fossils. Journal of Paleontology 49: 559-561.

Vidal B.C. 1977. Acid glycosaminoglycans and endochondral ossification: microespectrophotometric evaluation and macromolecular orientation. Cell Molecular Biology 22: 45-64. 